Link article (Style APA): Cheban, Yu. V., Chebykin O. Ya., Plokhikh V. V. \& Massanov A. V. (2020). Emotional factor of competitive self-mobilization of professional rowers. Insight: the psychological dimensions of society, 3, 28-43. DOI: 10.32999/2663-970X/2020-3-2

Link article (Style DSTU 8302: 2015): Cheban, Yu. V., Chebykin O. Ya., Plokhikh V. V. \& Massanov A. V. Emotional factor of competitive self-mobilization of professional rowers. Insight: the psychological dimensions of society, 2020, 3, 28-43. DOI: 10.32999/2663-970X/2020-3-2

UDC 159.942

\title{
Emotional factor of competitive self-mobilization of professional rowers
}

\author{
Емоційний фактор змагальної самомобілізації \\ спортсменів-веслувальників
}

Received: April 03, 2020 Accepted: May 12, 2020

\author{
Cheban Yurii Volodymyrovych \\ Graduate student, Department of Theory \\ and Practice of Practical Psychology \\ South Ukrainian National Pedagogical \\ University named after K. D. Ushynsky, Ukraine \\ kanoe_sila@mail.ru, \\ ORCID 0000-0002-9668-937X \\ Chebykin Oleksiy Yakovych \\ Doctor of Psychology, Full Professor, \\ Academician Department of Theory \\ and Practice of Practical Psychology \\ South Ukrainian National Pedagogical \\ University named after K. D. Ushynsky, Ukraine \\ rector@pdpu.edu.ua, \\ ORCID 0000-0001-7905-2708
}

Plokhikh Viktor Volodymyrovych

Doctor of Psychological Sciences, Full

Professor, Department of Developmental

Psychology and Social Communications

South Ukrainian National Pedagogical

University named after K. D. Ushynsky, Ukraine

plokhikh_v@ukr.net,

ORCID 0000-0001-7897-3417

Massanov Anatolii Viktorovych

Doctor of Psychological Sciences, Full

Professor, Department of Developmental

Psychology and Social Communications

South Ukrainian National Pedagogical

University named after K. D. Ushynsky, Ukraine massa@meta.ua,

ORCID 0000-0002-1002-4941
Чебан Юрій Володимирович

Аспірант, Кафедра теорії та методики практичної психології

Південноукраїнський національний педагогічний університет імені

К.Д. Ушинського, Україна kanoe_sila@mail.ru,

ORCID 0000-0002-9668-937X

Чебикін Олексій Якович

Доктор психологічних наук, професор, академік Кафедра теорії та методики практичної психології

Південноукраїнський національний педагогічний університет імені

К.Д. Ушинського, Україна rector@pdpu.edu.ua,

ORCID 0000-0001-7905-2708

Плохіх Віктор Володимирович

Доктор психологічних наук, професор, Кафедри психології розвитку і соціальних комунікацій

Південноукраїнський національний педагогічний університет імені

К.Д. Ушинського, Україна plokhikh_v@ukr.net,

ORCID 0000-0001-7897-3417

Массанов Анатолій Вікторович

Доктор психологічних наук, професор

Кафедри психологї̈ розвитку

і соціальних комунікацій

Південноукраїнський національний педагогічний університет імені

К.Д. Ушинського, Україна massa@meta.ua,

ORCID 0000-0002-1002-4941 


\section{Emotional factor of competitive self-mobilization of professional rowers}

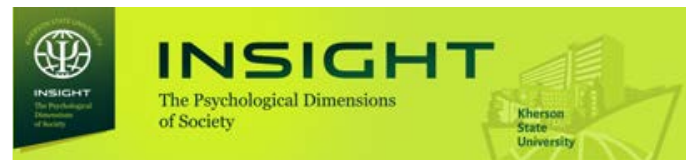

\section{Abstract}

Based on the provisions of the differential emotions theory, psychology of attitude, self-regulation concepts, the authors study the influence of emotiogenic stimuli and stressors (emotional factor) on the competitive self-mobilization of professional rowers. The purpose of the research is to determine the forms and sources of competitive self-mobilization of professional rowers under the conditions of influence of emotiogenic stimuli. The following methods were used in the empirical part: natural experiment, questionnaire for the evaluation of the frequency of use of mental resources in the competitive practice (image constructs, verbal forms) and experience of support of emotiogenic stimuli of a situation; testing for the identification of the frequency of experience of basal emotions, the motivation for success, and emotional personality traits. According to experimental design, to identify the capacity to overcome fatigue, the study participants have been passing a control distance of $150 \mathrm{~m}$ before and after intense training. The participants were 41 professional rowers of whom 27 are National Team members. Results. It is established that positive emotions of joy and pleasure significantly prevail (Friedman test) over negative ones $(\chi 2=79.823$; df $4 ; \mathrm{p}<.001)$ in the emotional state of athletes' activities. The athletes' motivation for success is associated with joy $(R s=.337 ; \mathrm{p}=.031)$ and pleasure $(R s=.398 ; \mathrm{p}=.010)$. Athletes feel especially vivid emotional support from relatives $(\chi 2=45.343 ; \mathrm{df}=4 ; \mathrm{p}<.001)$. The verbal formulas are often used for self-mobilization. Among image constructs, athletes commonly apply preliminary self-identification with the Winner $(\chi 2=69.676$; $\mathrm{df}=5 ; \mathrm{p}<.001$ ). The use of an image of "powerful mechanism" is connected with the motivation for success $(R s=.521 ; \mathrm{p}<.001)$ that contributes to the improvement of the overall performance of competitive self-mobilization of athletes. The research concludes about the need to study the joint influence of emotional factor and volitional powers of professional rowers on the competitive self-mobilization.

Key words: emotions, self-mobilization, attitude, success driver, professional rower.

\section{Introduction}

Modern sports significantly raise standards for the training and performance of high qualified athletes, along with results increase. To realize the technical and tactical potential in its entire, an athlete should set himself up for solving competitive task and "be" in a zone of optimal functioning of psyche and body through mastering

\section{Анотація}

На основі положень теорії диференційних емоцій, психології установки, концепцій саморегуляції розглядається вплив емоціогенних стимулів та стресорів (емоційний фактор) на змагальну самомобілізацію спортсменів-веслувальників. Метою дослідження $\epsilon$ визначення форм та джерел змагальної самомобілізації спортсменів-веслувальників в умовах впливу емоціогенних стимулів. В емпіричній частині застосовано наступні методи: природний експеримент; анкетування для оцінки частот використання у змагальній практиці ментальних ресурсів (образних конструктів, словесних форм) та переживання підтримки з боку емоціогенних стимулів ситуації; тестування для визначення частот переживання базальних емоцій, мотивації успіху, емоційних особистісних особливостей. За експериментальним планом для визначення здатності до подолання втоми досліджувані проходили контрольну дистанцію в 150 м до та після напруженого тренування. Досліджуваними були 41 спортсмен-веслувальник, 3 яких 27 - члени Національної збірної. Результати. Встановлено, що в емоційному фоні життєдіяльності спортсменів позитивні емоції радості та задоволення суттєво переважають (критерій Фрідмана) над негативними емоціями $(\chi 2=79.823 ; \mathrm{df} 4 ; \mathrm{p}<.001)$. Мотивація успіху спортсменів пов'язана з радістю $(R s=.337 ; \mathrm{p}=.031)$ й задоволенням $(R s=.398 ; \mathrm{p}=.010)$. Особливо виразну емоційну підтримку спортсмени відчувають з боку родичів $(\chi 2=45.343 ; \mathrm{df}=4 ; \mathrm{p}<.001)$. Для самомобілізації часто застосовуються словесні формули. Серед образних конструктів дуже часто спортсмени застосовують завчасне уявлення себе як Переможця ( $\chi 2=69.676 ; \mathrm{df}=5 ; \mathrm{p}<.001)$. Застосування образу «могутнього механізму» пов'язане і з мотивацією успіху (Rs=.521; р<.001), і сприяє підвищенню загальної ефективності змагальної самомобілізації спортсменів. Робиться висновок про необхідність розгляду поєднаного впливу емоційного фактору та вольових якостей спортсменів-веслувальників на змагальну самомобілізацію.

Ключові слова: емоції, самомобілізація, установка, мотив успіху, спортсмен-веслувальник.

\section{Вступ}

У сучасному спорті, разом із зростанням результатів, суттєво підвищуються вимоги до підготовки та виступу спортсменів вищої кваліфікації. Для всебічної реалізації технічного та тактичного потенціалу спортсмен повинен бути налаштований на вирішення змагального завдання й через долання дестабі- 
a destabilizing influence of numerous stressors (Gould et al., 2017).

In the high-speed, strength, difficulty coordinating rowing, an athlete overcomes direct resistance of natural conditions (water environment, wind, air temperature) and subjective restrictions while solving a competitive task (Kolumbet, 2017; Miarka et al., 2018; Strykalenko et al., 2019). The latter ones, together with weaknesses in technical, physical and tactical training, should include strong emotional experience the structure of which is sophisticated before, during and after the performance and emotiogenic stimuli are numerous and diverse. The expressive stressors of an athlete's performance are the responsibility for the result, anxiety due to failure consequences and lack of self-trust (Agisheva etal., 1982; Alekrinskis et al., 2019). In addition to the above emotiogenic stimuli in numerous links and chains, there are many others which influence a subject both in positive (constructive) and negative (destructive) aspects. In real practice, against the background of general psycho-emotional stress, any circumstance causing indignation can become an emotiogenic one (Chebykin et al., 2017; Ekman, 2004; Izard, 1991). As a result, besides the before mentioned stressors, it occurs images, signs, phrases, emotional personality traits associated with important objects and situations, as well as elements of the environment represented by a coach, friends, relatives, fans, opponents, natural conditions. All these emotions' generators of an athlete's emotions as a whole can be considered as an emotional factor. The very influence of an emotional factor on sporting performance primarily depends on the subject's ability to self-regulate and self-mobilize. Moreover, optimally the process of self-mobilization should be organized in such a way that his resultant will contribute to the advancement of athlete's self-confidence, promotion of motivation for success, consolidation of actual competitive attitude under any conditions (Agisheva et al., 1982).

Options of the organization of the self-mobilization process of professional rowers in the context of the diverse influence of emotiogenic stimuli are mainly determined by the functions of emotions. In this regard, P. Fress focuses on the compensatory function of emotions aimed at eliminating excitement redundancy (Fress, 1975). In the light of such comprehension of the emotional process, лізуючого впливу численних стресорів “бути" в зоні оптимального функціонування психіки та організму (Gould et al., 2017).

У швидкісному, силовому, складно координованому веслувальному спорті спортсмен при вирішенні змагального завдання долає безпосередній опір природних умов (водне середовище, вітер, температура повітря) й суб'єктивних обмежень (Kolumbet, 2017; Miarka et al., 2018; Strykalenko et al., 2019). До останніх, поряд з недоліками в технічній, фізичній та тактичній підготовці, слід віднести значні емоційні переживання, структура яких до, під час та після виступів складно організована, а емоціогенні стимули - численні й різноманітні. Виразними стресорами виступу спортсмена $є$ відповідальність за результат, тривога за наслідки невдач, невпевненість у власних силах та можливостях (Agisheva et al., 1982; Alekrinskis et al., 2019). До означених емоціогенних стимулів у численних сполученнях та зв'язках додається багато інших, які впливають на суб'єкт як у позитивному (конструктивному), так і в негативному (деструктивному) аспектах. В реальності на фоні загальної психоемоційної напруги будь-яка обставина, що викликає збурення, може стати емоціогенною (Chebykin et al., 2017; Ekman, 2004; Izard, 1991). Як наслідок, поряд з уже вказаними стресорами постають асоційовані 3 важливими об'єктами та ситуаціями образи, знаки, фрази, емоційні особистісні особливості, а також складові обстановки у вигляді тренера, друзів, родичів, вболівальників, суперників, природних умов. Всі ці джерела емоцій спортсмена у зв'язку та в комплексі й можуть бути визначені як емоційний фактор. I те, яким саме буде вплив емоційного фактору на спортивний виступ, насамперед залежить від здатності суб'єкта до саморегуляції та самомобілізації. Причому в оптимальному варіанті процес самомобілізації повинен бути організованим так, щоб його результуюча в будь-яких обставинах сприяла підвищенню впевненості спортсмена у своїх силах, підсиленню мотивації успіху, укріпленню актуальної змагальної установки (Agisheva et al., 1982).

Можливості організації процесу самомобілізації у спортсменів-веслувальників в умовах різноманітного впливу емоціогенних стимулів значною мірою визначаються функціями 
self-mobilization of an athlete under the stressful conditions is limited to the role of kind of "relief valve". Besides, such emotions as joy and pleasure are studied from the perspective of their inspiring, activating influence on the activity. In this case, the motivational function of emotions is pervasive.

Emotions as a basis of the motivational system of human activities are thoroughly considered in differential emotions theory (Izard, 1991). From the standpoint of this conceptual approach, the emotions (especially basal ones) are powerful motivator of the behavioral reactions.

To perform actions, a rower primarily maintains a well-mastered (often until it became the second nature) action program which already has the relevant balanced motivational component. At the same time, the process of self-mobilization is mostly reduced to the optimization of the intensity of stimuli described in the Yerkes-Dodson law through their expedient intensification or weakening. Optimization changes of the arousal level of an athlete are associated with the key competitive motive - the motive for success (Gould et al., 2017; Popovych et al., 2019). As a result, when there is an expressive emotional experience of fear and sadness, the self-mobilization of an athlete should act towards the strengthening of motivation for success and required increase of activity level. In the case of hyper arousal, for instance, caused by anger or the state of untimely euphoria, the process of self-regulation concentrates on the processing and re-orientation of the actualization of activity redundancy.

According to the provisions of differential emotions theory, the initial instant of emotional process is the subject's evaluation of the external influence and overall situation. Such initial evaluation is unconscious and inevitable (Ekman, 2004). If the influence is assessed as significant, an emotion emerges. But the subsequent development of the emotional process can be consciously controlled by the subject that is based on the experience of self-regulation, the actualization of particular personality traits and mental resources.

The emotional process covers the entire body and psyche. Besides, the related response takes place in vegetative and neuromuscular systems and is experienced and realized in a special mode. The emotional process in development is structured in such a way that critical changes in емоцій. У цьому аспекті П. Фресс акцентує увагу на компенсаторній функції емоцій, призначеній для усунення надлишку збудження (Fress, 1975). В такому розумінні емоційного процесу самомобілізація спортсмена в напружених умовах обмежується лише роллю своєрідного «запобіжного клапану». Поряд із цим, такі емоції як радість та задоволення розглядаються саме з позиції їх надихаючого, активуючого впливу на діяльність. I в цьому випадку на провідні позиції вже виходить мотиваційна функція емоцій.

Емоції, як основу мотиваційної системи життєдіяльності людини, грунтовно розглянуто в диференційній психології емоцій (Izard, 1991). 3 позицій цього концептуального підходу емоції (особливо базальні) є могутніми мотиваторами поведінкових реакцій.

Веслувальник для виконання дій насамперед актуалізує добре відпрацьовану (часто-густо до автоматизму) програму дій, яка вже містить відповідний збалансований мотиваційний компонент. При цьому процес самомобілізації здебільшого зводиться до описаної в законі Йоркса-Додсона оптимізації інтенсивності спонукань через їх доцільне підсилення або послаблення. Оптимізаційні ж зміни рівня активності спортсмена насамперед стосуються ключового змагального мотиву - мотиву успіху (Gould et al., 2017; Popovych et al., 2019). Як наслідок, при виникненні виразних переживань страху та суму самомобілізація у спортсмена повинна розгортатися в напрямку підсилення мотивації успіху і необхідного підвищення рівня активності. У випадку ж надмірного збудження, наприклад у гніві чи у стані невчасної ейфорії, процес саморегуляції спрямовується на перетворення та переорієнтування реалізації надлишку активності.

Згідно з положеннями диференційної психології емоцій початковим моментом емоційного процесу є оцінка суб'єктом значення стороннього впливу і загальної ситуації. Така первинна оцінка $\epsilon$ неусвідомлюваною і неминучою (Ekman, 2004). Якщо вплив оцінено як суттєвий, емоція виникає обов'язково. Але наступний розвиток емоційного процесу може бути поставлений суб'єктом під свідомий контроль, який підкріплюється досвідом саморегуляції, актуалізацією відповідних особистісних особливостей та ментальних ресурсів. 
one of its components result in peculiar transformations of others. The latter fact is a basis for conscious self-regulation and self-mobilization of an athlete.

In the process of self-regulation, an athlete can focus on the changes in the individual components of the emotional state by re-directing attention controlling intensity and depth of breathing, intensifying or weakening emotional expression "producing" the sense of warmth or coolness (Prokhorov, 2017). Moreover, the self-regulation can be more fundamental through transforming a notional attitude into the activity with the use of specific emotional and cognitive structures and orientations (Izard, 1991). Such structures in the forms of mental resources (image constructs, verbal formulas) should change the very attitude of an athlete to the situation and himself. And all that is due to the actualization through the associations (even paradoxical) of additional and previously latent opportunities (Agisheva et al., 1982; McCormick et al., 2018; Wallace et al., 2017). At the same time, the general emotional state of the sporting activity, which is an essential component of the optimum functioning of the body and psyche, should become consolidated positively.

The purpose of the research is to determine the forms and sources of competitive self-mobilization of professional rowers under the conditions of influence of emotiogenic stimuli.

The tasks of the research are as follows:

1. To consider an alternative to use the provisions of differential emotions theory and concepts of self-regulation of a subject as a basis for the study of the emotional factor of competitive self-mobilization of professional rowers.

2. To determine the features of the influence of emotional stimuli and stressors of the competitive situation on the effectiveness of self-mobilization of professional rowers empirically.

\section{Methodology}

The research involves 41 professional rowers, of whom 27 persons are members of the National Team. Sports qualification of the study participants varies from the beginner to Honored Master of Sports. A level of the sports qualification of athletes is coded at the ordinal scale where the supreme qualification "Honored Master of Sports" is marked by "1" (coding from 1 to 7).
Емоційний процес охоплює увесь організм та психіку. При цьому пов'язане реагування відбувається у вегетативній та руховій системах, особливим чином переживається і усвідомлюється. Емоційний процес в розгортанні структурований так, що критичні зміни однієї 3 його складових мають наслідком характерні перетворення інших складових. Останнє і $\epsilon$ підгрунтям для свідомої саморегуляції та самомобілізації спортсмена.

Спортсмен у процесі саморегуляції може зосереджуватися на змінах в окремих компонентах емоційного стану, переорієнтовуючи увагу, контролюючи інтенсивність й глибину дихання, підсилюючи або послаблюючи емоційну експресію, «викликаючи» відчуття тепла та прохолоди (Prokhorov, 2017). Але саморегуляція може бути й більш фундаментальною через перетворення смислової установки на діяльність з застосуванням відповідних афективно-когнітивних структур та орієнтацій (Izard, 1991). Такі структури в якості ментальних ресурсів (образних конструктів, словесних формул) повинні змінювати саме відношення спортсмена до ситуації та до себе. I все це - завдяки актуалізації через асоціації (навіть парадоксальні) додаткових і також раніше непроявлених можливостей (Agisheva et al., 1982; McCormick et al., 2018; Wallace et al., 2017). При цьому загальний емоційний фон спортивної діяльності, який $є$ необхідною складовою зони оптимального функціонування організму і психіки, повинен стверджуватися у позитиві.

Мета дослідження - визначення форм та джерел змагальної самомобілізації спортсменів-веслувальників в умовах впливу емоціогенних стимулів.

Завдання дослідження:

1. Розглянути можливість використання положень теорії диференційних емоцій та концепцій саморегуляції суб'єкта в якості основи дослідження емоційного фактору змагальної самомобілізації спортсменів-веслувальників;

2. Емпірично визначити особливості впливу емоціогенних стимулів та стресорів змагальної ситуації на ефективність самомобілізації спортсменів-веслувальників.

\section{Методологія}

У дослідженні брали участь 41 спортсмен-веслувальник, 3 яких 27 осіб - члени 
Every degree in the lowering of sports qualification corresponds to the addition of a point at the ordinal scale.

The empirical research studies the competitive self-mobilization of professional rowers as an actual attitude (aimed readiness) combining motivation for success and emotiogenic components of a competitive situation (stressors, emotional stimuli, emotional characteristics of a person, mental resources). Mental resources are conscious emotional and cognitive structures in the form of selected verbal formulas and image constructs. It is considered that the mechanisms of self-mobilization are maintained by athletes when required to come with such stressors of the competitive situation as emotional tension caused by anxiety due consequences of the failed performance and lack of self-confidence, physical fatigue (Agisheva et al., 1982; Alekrinskis et al., 2019). Taking into account the above, sports achievements of the participants, which are formalized by their sports qualification, can be considered as an important and reliable index of effectiveness of the competitive self-mobilization.

The ability of the participants to overcome physical fatigue is evaluated according to the results of the natural experiment (quasi-experiment). Fatigue of professional athletes after the intensive training is an independent variable in the experimental context, and the dependent variable is time for passing a control distance $(150 \mathrm{~m})$. Before the implementation of the experimental task, the participants have focused on the speediest time of passing the distance. The control distance has been passed two times: before (after warm-up activity) and after the basic training. When conducting the research, members of the National Team have been intensively preparing for the World Championships and others - for regional competitions. Intense training load has resulted in physical fatigue of athletes at the moment of the training completion. That fatigue has been a factor of progress in the second experimental race.

The control distance has been marked at the rowing canal through special buoys located at $50 \mathrm{~m}$ from each other. A coach and an experimenter, who have accompanied the race on the boat, have maintained the time tracking of the passing of distance by the participants. The departure time was fixed via timer and paper. The
Національної збірної команди. Спортивна кваліфікація досліджуваних була від початківця до Заслуженого майстра спорту. Рівень спортивної кваліфікації спортсменів кодувався на порядковій шкалі, на якій найвища кваліфікація "Заслужений майстер спорту" позначалася як “1” (кодування від 1 до 7). Кожному ступеню у зниженні спортивної кваліфікації відповідало додавання одиниці на порядковій шкалі.

В емпіричному дослідженні змагальна самомобілізація спортсменів-веслувальників розглядалася як актуальна установка (спрямована готовість), що поєднує мотивацію досягнення успіху й емоціогенні складові змагальної ситуації (стресори, емоціогенні стимули, емоційні властивості особистості, ментальні ресурси). Ментальними ресурсами $\epsilon$ усвідомлювані афективно-когнітивні структури у вигляді спеціально відібраних словесних формул і образних конструктів. Вважається, що механізми самомобілізації за необхідністю актуалізуються спортсменами для подолання таких стресорів змагальної ситуації, як: емоційна напруга, що зумовлена тривогою за наслідки невдалого виступу та невпевненістю у власних можливостях; фізична втома (Agisheva et al., 1982; Alekrinskis et al., 2019). 3 огляду на це спортивні досягнення досліджуваних, які формалізовано їх спортивною кваліфікацією, можуть розглядатися як важливий і надійний показник ефективності змагальної самомобілізації.

Здатність досліджуваних щодо подолання фізичної втоми оцінювалася за результатами природного експерименту (квазіексперименту). Незалежною змінною в експериментальному плані була втома спортсменів-веслувальників після інтенсивного тренування, залежною - час подолання контрольної дистанції (150 м). Досліджувані перед виконанням експериментального завдання налаштовувалися на найвищу швидкість проходження дистанції. Контрольна дистанція долалася два рази: до (після розминки) та після основного тренування. На момент проведення дослідження члени Національної збірної команди інтенсивно готувалися до Чемпіонату світу, а інші досліджувані - до регіональних змагань. Насичене тренувальне навантаження зумовлювало фізичну втому спортсменів на момент завершення тренування. Ця втома й була фак- 
time correlation of the second and the first time (t2/t1) is an indicator of a participant's ability to overcome fatigue (an indicator of fatigue overcoming). It is considered that when the time of the second race increases and the indicator of the ratio decreases, an athlete's ability to self-mobilize in a state of physical fatigue is higher.

In the context of the questionnaire, the participants have evaluated the frequency of the use of emotional and cognitive structures (mental resources) in the form of verbal formulas and image constructs of objects and processes in the sports practice. Besides, the participants have evaluated the frequencies of emotional stress caused by such external emotional stimuli as a coach, friends, fans, relatives, natural conditions (due to the ambiguity of emotional influence of opponents, this problem should be studied separately). The frequencies of the professional rowers' emotional experience of external support and frequencies of the use of mental resources are identified through such an ordinal scale: never (1); very seldom (2); seldom (3); often (5); very often (6); always (7).

The proposed verbal formulas by the nature of the influence can be attributed to direct and indirect self-suggestion and self-persuasion (Agisheva et al., 1982). The participants have been offered to evaluate the frequency of use of the following verbal formulas: self-order ("Hurry up!" Go to it!); self-persuasion ("If I do .., it will result in..."); self-encouragement ("I can step up!"); self-suggestion ("I'm enduring. I'm strong. I can do it!"); self-sacrifice ("Only Victory; and whatever it takes"). Image constructs are defined in such a way that they symbolize characteristics of self-confidence, strength of efforts, bravery, indefatigability, resoluteness necessary for a rower (Alekrinskis et al., 2019; Cheban, 2018).The participants have evaluated the frequency of use of the following image constructs: "strict Authority"; self-identification with "Idol"; "Imagination of Victory"; self-identification with the "force of nature"; self-identification with the "ferocious beast"; self-identification with a "powerful mechanism".

The participants have been diagnosed with motivation for success (T. Ehlers test) and emotional personality traits (16PF Questionnaire of R. Cattell). Determination of the predominant components of the emotional state of the life-sustaining activities of rowers has been carried out according to T. Dembo method of cognitive self-as- тором успішності другого експериментального заїзду.

Контрольна дистанція відмічалася на гребному каналі за допомогою спеціальних буїв, які розташовувалися на відстані 50 м один від одного. Хронометраж проходження дистанції досліджуваними виконувався тренером та експериментатором, які супроводжували заїзд на катері. Час заїзду відмірювався за допомогою секундоміру й фіксувався на папері. В якості індикатора здібності досліджуваного до подолання втоми (індикатор подолання втоми) приймалося відношення часу другого заїзду до часу першого (t2/t1). Вважалося, що зі зменшенням часу другого заїзду й, відповідно, зі зменшенням значення вказаного відношення, здібність спортсмена до самомобілізації у стані фізичної втоми - вище.

В запропонованій анкеті досліджувані оцінювали частоту використання у спортивній практиці афективно-когнітивних структур (ментальних ресурсів) у вигляді словесних формул і образних конструктів об'єктів і процесів. Поряд із цим досліджувані оцінювали частоти переживань від таких зовнішніх емоціогенних стимулів, як: тренер, друзі, вболівальники, родичі, природні умови (через неоднозначність емоціогенного впливу суперників цю проблематику слід розглядати окремо). Частоти переживань спортсменами-веслувальниками зовнішньої підтримки та частоти використання ментальних ресурсів визначалися за такою порядковою шкалою: ніколи (1); дуже рідко (2); рідко (3); іноді (4); часто (5); дуже часто (6); завжди (7).

Запропоновані словесні формули за характером впливу можуть бути віднесені до прямих та непрямих самонавіювань, до самопереконання (Agisheva et al., 1982). Досліджуваним пропонувалося оцінити частоту застосування наступних словесних формул: самонаказ (“Швидше! Підналягти!”); самопереконання (“Якщо зроблю ..., то буде ...”); самопідбадьорення (“А ще ж можу підналягти!”); самонавіювання (“Я витривалий. Я сильний. Я зможу”); самовідданість ("Тільки Перемога, і будь, що буде"). Образні конструкти визначалися так, щоб вони символізували необхідні для веслувальника якості впевненості у собі, могутності зусилля, сміливості, невтомності, рішучості (Alekrinskis et al., 2019; Cheban et al., 2020). 
sessment of basal emotions. The participants have been proposed to evaluate the frequency of the emergence of some basal emotions (joy, fear, pleasure, anger, sadness) using the above 7-points scale.

Thus, the empirical research marks the following criteria regarding the participants: sports qualification, an indicator of fatigue overcoming $(t 2 / t 1)$; frequencies of the emergence of basal emotions; frequencies of the use of verbal formulas and image constructs; frequencies of the emotional experience of support from the external emotional stimuli; motivation for success; emotional stability ( $\mathrm{C}$ factor); anxiety ( $\mathrm{O}$ factor). The quantitative analysis has been performed via IBM SPSS Statistics 20. The correlation analysis (according to Spearman) and $\chi 2$ - Friedman test has been used.

\section{Results}

For the study groups, it has been established a direct correlation between the indices of self-mobilization represented by sports qualification and indicator of fatigue overcoming ( $R s=.581$; $\mathrm{p}<.001$ ).
Досліджувані оцінювали частоту застосування таких образних конструктів: "суворий Авторитет”; самоідентифікація з “Кумиром”; “уявлення Перемоги"; самоідентифікація з "природною стихією”; самоідентифікація з “лютим звіром"; самоідентифікація 3 "могутнім механізмом". Образні конструкти не конкретизувалися.

У досліджуваних діагностувалися мотивація успіху (тест Т. Елерс) та емоційні властивості особистості (опитувальник Р. Кеттелла 16 PF). Визначення провідних складових емоційного фону життєдіяльності спортсменів-веслувальників проводилося за методикою когнітивної самооцінки базальних емоцій Т. Дембо. Досліджуваним пропонувалося оцінювати частоту появи низки базальних емоцій (радість, страх, задоволення, гнів, сум) з використанням описаної вище 7-бальної шкали.

Таким чином, в емпіричній роботі щодо досліджуваних визначалися такі показники: спортивна кваліфікація, індикатор подолання втоми (t2/t1); частоти появи базальних емоцій; частоти використання словесних формул і образних конструктів; частоти переживання підтримки від зовнішніх емоціогенних сти-

Table 1. Statistical comparison of the frequencies of participants' emotional experience of basal emotions ( $\chi 2$ - Friedman criterion)

Таблиця 1. Статистичне порівняння частот переживання досліджуваними базальних емоцій ( $\chi 2$ - критерій Фридмана)

\begin{tabular}{|c|c|c|c|c|c|}
\hline \multirow{2}{*}{$\begin{array}{c}\text { Statistical parameter } \\
\text { Статистичний параметр }\end{array}$} & \multicolumn{5}{|c|}{$\begin{array}{c}\text { Вasal emotions } \\
\text { Базальні емоції }\end{array}$} \\
\cline { 2 - 6 } & $\begin{array}{c}\text { Joy } \\
\text { Радість }\end{array}$ & $\begin{array}{c}\text { Pleasure } \\
\text { Задоволення }\end{array}$ & $\begin{array}{c}\text { Fear } \\
\text { Страх }\end{array}$ & $\begin{array}{c}\text { Anger } \\
\text { Гнів }\end{array}$ & $\begin{array}{c}\text { Sadness } \\
\text { Сум }\end{array}$ \\
\hline Me & 6 & 5 & 3 & 3 & 3 \\
\hline $\min$ & 4 & 3 & 2 & 1 & 1 \\
\hline $\max$ & 7 & 7 & 7 & 6 & 7 \\
\hline$\chi 2$ & \multicolumn{7}{|c|}{$79.823(\mathrm{df}=4 ; \mathrm{p}<.001)$} \\
\hline
\end{tabular}

Table 2. Statistical comparison of participants' emotional experience of support from the external emotional stimuli of the competitive situation ( $\chi 2$ - Friedman criterion) Таблиця 2. Статистичне порівняння частот переживання досліджуваними підтримки з боку зовнішніх емоціогенних стимулів змагальної ситуації ( $\chi 2$ - критерій Фридмана)

\begin{tabular}{|c|c|c|c|c|c|}
\hline $\begin{array}{c}\text { Statistical parameter } \\
\text { Статистичний } \\
\text { параметр }\end{array}$ & \multicolumn{5}{|c|}{$\begin{array}{c}\text { Еmotional stimuli of the competitive situation } \\
\text { Емоціогенні стимули змагальної ситуації }\end{array}$} \\
\cline { 2 - 6 } & $\begin{array}{c}\text { Coach } \\
\text { Тренер }\end{array}$ & $\begin{array}{c}\text { Friends } \\
\text { Друзі }\end{array}$ & $\begin{array}{c}\text { Fans } \\
\text { Вболівальники }\end{array}$ & $\begin{array}{c}\text { Relatives } \\
\text { Родичі }\end{array}$ & $\begin{array}{c}\text { Natural conditions } \\
\text { Природні умови }\end{array}$ \\
\hline Ме & 5 & 5 & 4 & 7 & 5 \\
\hline $\min$ & 2 & 3 & 1 & 2 & 7 \\
\hline $\max$ & 7 & 7 & 7 & 7 & 7 \\
\hline$\chi^{2}$ & \multicolumn{5}{|c|}{$45.343(\mathrm{df}=4 ; \mathrm{p}<.001)$} \\
\hline
\end{tabular}


To identify the predominant emotional state oflife-sustaining activities of the participants, the researchers have compared the frequencies of their emotional experience of positive and negative basal emotions (table 1 ).

Emotions of joy and pleasure essentially prevail over almost equally arising $(\chi 2=2.730 ; \mathrm{df}=2$; $\mathrm{p}=.255$ ) negative emotions of fear, anger and sadness (see table 1) in the emotional state of the life activities of the studied groups. Moreover, the correlational analysis shows a direct connection for the frequencies of the emergence of positive emotions of joy and pleasure $(R s=.481 ; p=.001)$, as well as for negative emotions of fear and anger (Rs=.337; $\mathrm{p}=.031$ ) and sadness ( $R s=.324 ; \mathrm{p}=.039$ ). The frequencies of the emergence of joy and sadness are related conversely(Rs=-.433; $\mathrm{p}=.005)$. The motivation for success is often directly associated with the frequency of experience of joy (Rs=.337; $\mathrm{p}=.031$ ) and pleasure(Rs=.398; $\mathrm{p}=.010)$, as well as conversely - the frequencies of sadness $(R s=-.403 ; \mathrm{p}=.009)$ and anger (tendency level: $R s=-.283$; $\mathrm{p}=.073$ ). The motivation for success relates to the indicator of fatigue overcoming (Rs=-.430; p=.005) and sports qualification (Rs=-.378; $\mathrm{p}=.015$ ). The frequency of experience of anger is associated with the indicator of fatigue overcoming (Rs=-.378; $\mathrm{p}=.015$ ).

The frequencies of participants' emotional experience of support from the external emotional stimuli are represented in the table 2 .

Emotional stability (Rs=-.357; p=.022) and anxiety $(R s=.334 ; \mathrm{p}=.033)$ are associated with the sports qualification among the emotional personal traits. It is established a correlation of the indicator of fatigue overcoming with anxiety $(R s=.313 ; \mathrm{p}=.046)$. In addition, motivation for success directly relates to emotional stability and conversely - to anxiety $(R s=-.344$; $\mathrm{p}=.028$ ).

The frequencies of the participants' use of mental resources (image constructs and verbal formulas) differ (fig. 1). Statistical comparison (Friedman criterion) of the frequencies of the use of mental resources of self-mobilization in the group shows differences both for verbal formulas $(\chi 2=10.468 ; \mathrm{df}=4 ; \mathrm{p}=.033)$ and image constructs $(\chi 2=69.676 ; \mathrm{df}=5 ; \mathrm{p}<.001)$.

Frequencies of the use of mental resources by the participants are associated with the emotiogenic influence of the stimuli of the competitive мулів; мотивація успіху; емоційна стійкість (фактор С); стурбованість (фактор 0). Кількісний аналіз даних проводився 3 використанням статистичного пакету IBM SPSS Statistics 20. Застосовувалися кореляційний аналіз (за Спірменом) та $\chi 2$ - критерій Фридмана.

\section{Результати}

Для досліджуваної групи встановлено прямий зв'язок між показниками самомобілізації, що представлені спортивною кваліфікацією та індикатором подолання втоми (Rs=.581; p<.001).

3 метою визначення переважного емоційного фону життєдіяльності досліджуваних зіставлялися частоти переживань ними позитивних та негативних базальних емоцій (табл. 1).

В емоційному фоні життєдіяльності досліджуваних групи суттєво переважають емоції радості та задоволення над практично однаково виникаючими $(\chi 2=2.730 ; \mathrm{df}=2 ; \mathrm{p}=.255)$ негативними емоціями страху, гніву та суму (див. табл.1). До того ж, кореляційний аналіз показав прямий зв'язок для частот появи позитивних емоцій радості та задоволення $(R s=.481 ; \mathrm{p}=.001)$, а також для негативної емоції страху з гнівом $(R s=.337 ; \mathrm{p}=.031)$ і сумом $(R s=.324 ; \mathrm{p}=.039)$. Частоти появи радості та суму пов'язані зворотно (Rs=-.433; $\mathrm{p}=.005)$. 3 мотивацією успіху прямо пов'язано частоту переживання радості $(R s=.337 ; \mathrm{p}=.031)$ й задоволення $(R s=.398 ; \mathrm{p}=.010)$, а також зворотно частоти суму $(R s=-.403 ; \mathrm{p}=.009)$ й гніву (рівень тенденції: $R s=-.283 ; \mathrm{p}=.073)$. Мотивацію успіху пов'язано з індикатором долання втоми $(R s=-$ $.430 ; \mathrm{p}=.005)$ та із спортивною кваліфікацією ( $R s=-.378 ; \mathrm{p}=.015)$. Частота переживання гніву пов'язано 3 індикатором подолання втоми (Rs=.315; $\mathrm{p}=.045)$.

Частоти переживання досліджуваними підтримки з боку зовнішніх емоціогенних стимулів представлено в табл. 2.

3 емоціогенних особистісних особливостей зі спортивною кваліфікацією пов'язано емоційну стійкість (Rs=-.357; p=.022) та стурбованість $(R s=.334 ; \mathrm{p}=.033)$. Встановлено зв'язок індикатора долання втоми зі стурбованістю $(R s=.313 ; \mathrm{p}=.046)$. До того ж, мотивацію успіху прямо пов'язано 3 емоційною стійкістю $(R s=.342 ; \mathrm{p}=.029)$ та зворотно - із стурбованістю $(R s=-.344 ; \mathrm{p}=.028)$. 


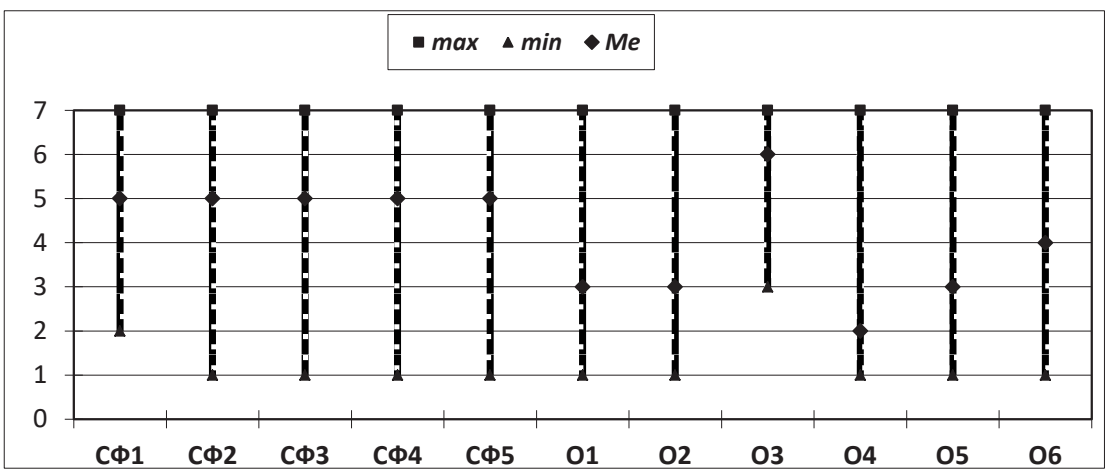

Note: verbal formulas: CФ1 - self-order, CФ2 - self-persuasion, СФ3 - selfencouragement, CФ4 - self-suggestion, CФ5 - selflessness; image constructs: O1 - "strict Authority", O2 - "Idol", O3 - "imagination of Victory", O4 - "force of nature", O5 ferocious beast", O6 - "powerful mechanism".

Примітка: словесні формули: СФ1 - самонаказ, СФ2 - самопереконання, СФ3 - самопідбадьорення, СФ4 - самонавіювання, СФ5 - самовідданість; образні конструкти: О1 - “суворий Авторитет”, О2 - “Кумир”, О3 - “уявлення Перемоги”, О4 - “природна стихія”, О5 - “лютий звір”, О6 - “могутній механізм”.

Fig. 1. Frequency characteristics of the use of mental resources (verbal formulas, imagine constructs) by the professional rowers for competitive self-mobilization

Рис. 1. Частотні характеристики використання спортсменами-веслувальниками ментальних ресурсів (словесних формул, образних конструктів) для змагальної самомобілізації

situation (table 3) and emotional personal traits. Thus, emotional stability directly correlates with a frequency of the use of the formula of selflessness (Rs=.386; $\mathrm{p}=.013)$ and an image of "powerful mechanism" (Rs=.377; p=.015), and anxiety conversely correlates with selflessness ( $R s=-.372$; $\mathrm{p}=.017)$ and "imagination of Victory" (Rs=-.392; $\mathrm{p}=.011)$.

The motivation for success is associated with the frequency of the use of a verbal formula "self-encouragement" (Rs=.350; $\mathrm{p}=.025)$, images of "ferocious beast" $(R s=.413 ; \mathrm{p}=.007)$ and "powerful mechanism" (Rs=.521; p<.001). Sports qualification correlates with the frequencies of the participants' use of the formulas of self-encouragement (Rs=-.311; $\mathrm{p}=.048)$ and selflessness (Rs=-.430; p=.005), as well as an image of "a powerful mechanism" (Rs=$.390 ; \mathrm{p}=.012$ ). The indicator of fatigue overcoming is associated with the frequencies of the use of the formula of self-suggestion ( $R s=.318 ; \mathrm{p}=.043$ ) and the image of "a powerful mechanism" (Rs=-.341; $\mathrm{p}=.029)$.
Частоти використання досліджуваними ментальних ресурсів (образних конструктів та словесних формул) відрізняються (рис. 1). Статистичне порівняння (критерій Фридмана) частот використання ментальних ресурсів самомобілізації в групі показало відмінності як для словесних формул ( $\chi 2=10.468 ; \mathrm{df}=4 ; \mathrm{p}=.033)$, так і для образних конструктів $(\chi 2=69.676$; $\mathrm{df}=5 ; \mathrm{p}<.001)$.

Частоти застосування досліджуваними ментальних ресурсів пов'язані з емоціогенним впливом стимулів змагальної ситуації (табл. 3) та з емоційними особистісними особливостями. Так, емоційна стабільність прямо корелює з частотою застосування формули самовідданості (Rs=.386; p=.013) й образу “могутнього механізму" (Rs=.377; p=.015), а стурбованість - зворотно з формулою самовідданості (Rs=-.372; р=.017) та "уявленням Перемоги" (Rs=-.392; р=.011).

Мотивацію успіху пов'язано 3 частотою застосування словесної формули "самопідбадьорення" (Rs=.350; p=.025), образів “лютого звіра" (Rs=.413; р=.007) та "могутнього меха- 
Table 3. The assessment of relations (according to Spearman) between the frequencies of the use of mental resources for self-mobilization and the frequencies of the emotional experiences of support from emotional stimuli of a competitive situation for the study group $(n=41)$

Таблиця 3. Для групи досліджуваних $(\mathrm{n}=41)$ оцінка зв'язків (за Спірменом) частот застосування для самомобілізації ментальних ресурсів з частотами переживання підтримки від емоціогенних стимулів змагальної ситуації

\begin{tabular}{|c|c|c|c|c|c|c|}
\hline \multirow[b]{2}{*}{$\begin{array}{l}\text { Mental resources } \\
\text { Ментальні ресурси }\end{array}$} & \multirow{2}{*}{$\begin{array}{c}\text { Statistical } \\
\text { parameter } \\
\text { Статистичний } \\
\text { параметр }\end{array}$} & \multicolumn{5}{|c|}{$\begin{array}{l}\text { Emotional stimuli of a competitive situation } \\
\text { Емоціогенні стимули змагальної ситуації }\end{array}$} \\
\hline & & $\begin{array}{l}\text { Coach } \\
\text { Tренер }\end{array}$ & $\begin{array}{l}\text { Friends } \\
\text { Друзі }\end{array}$ & $\begin{array}{c}\text { Fans } \\
\text { Вболівальники }\end{array}$ & $\begin{array}{l}\text { Relatives } \\
\text { Родичі }\end{array}$ & $\begin{array}{c}\text { Natural } \\
\text { conditions } \\
\text { Природні } \\
\text { умови } \\
\end{array}$ \\
\hline \multirow{2}{*}{$\begin{array}{l}\text { self-order } \\
\text { самонаказ }\end{array}$} & Rs & .134 & .408 & .355 & .434 & .287 \\
\hline & $\mathrm{p}$ & .402 & .008 & .023 & .005 & .069 \\
\hline \multirow{2}{*}{$\begin{array}{l}\text { self-persuasion } \\
\text { самопереконання }\end{array}$} & Rs & .027 & .017 & .426 & .373 & .239 \\
\hline & $\mathrm{p}$ & .866 & .914 & .005 & .016 & .132 \\
\hline \multirow{2}{*}{$\begin{array}{l}\text { self-encouragement } \\
\text { самопідбадьорення }\end{array}$} & Rs & -.053 & .312 & .321 & .263 & .326 \\
\hline & $\mathrm{p}$ & .742 & .047 & .041 & .097 & .037 \\
\hline \multirow{2}{*}{$\begin{array}{l}\text { self-suggestion } \\
\text { самонавіювання }\end{array}$} & Rs & .152 & .113 & .561 & .246 & .219 \\
\hline & $p$ & .344 & .480 & .000 & .122 & .169 \\
\hline \multirow{2}{*}{$\begin{array}{c}\text { selflessness } \\
\text { самовідданість }\end{array}$} & Rs & .240 & .329 & .226 & .280 & .348 \\
\hline & $\mathrm{p}$ & .130 & .036 & .155 & .076 & .026 \\
\hline \multirow{2}{*}{$\begin{array}{c}\text { "strict Authority" } \\
\text { “суворий Авторитет” }\end{array}$} & Rs & .240 & -.034 & .339 & .182 & .134 \\
\hline & $\mathrm{p}$ & .131 & .831 & .030 & .255 & .405 \\
\hline \multirow{2}{*}{$\begin{array}{l}\text { "imagination of Victory" } \\
\text { "уявлення Перемоги" }\end{array}$} & Rs & .413 & .346 & .006 & .086 & .219 \\
\hline & $\mathrm{p}$ & .007 & .027 & .971 & .594 & .169 \\
\hline
\end{tabular}

\section{Discussion}

Interrelated positive emotions of joy and pleasure (see table 1) prevail in the emotional state of the life activities of professional rowers. Taking into account relations peculiar to the motive for success, it is essential to add the emotion of interest (Izard, 1991). Positive emotions not only lead to the activation of body energy but also roundly contribute to the coherence and constructive implementation of cognitive processes and actions. In contrast, although the emotion of anger contributes to a significant activation of the body, it is destructive. Such a result is fully consistent with the provisions of differential emotions theory, which genetically link anger with impulsivity and incoherence of human actions (Ekman, 2004; Izard, 1991). At the same time, the connection between the emotions of joy and pleasure and the motivation for success is remarkable. First of all, the motivational function of emotions, rather than the compensatory one, consolidates in the structure of activities of the professional нізму" (Rs=.521; р<.001). Спортивна кваліфікація корелює з частотами застосування досліджуваними формул самопідбадьорення $(R s=-.311 ; \mathrm{p}=.048)$, та самовідданості $(R s=-.430$; $\mathrm{p}=.005)$, а також образу “могутнього механізму" (Rs=-.390; $\mathrm{p}=.012)$. Індикатор подолання втоми пов'язано з частотами застосування формули самонавіювання (Rs=.318; p=.043) та образу "могутнього механізму" (Rs=-.341; $\mathrm{p}=.029$ ).

\section{Дискусія}

В емоційному фоні життєдіяльності спортсменів-веслувальників переважають взаємопов'язані позитивні емоції радості та задоволення (див. табл. 1). До цього ж переліку, 3 урахуванням притаманних мотиву успіху зв'язків, слід додати й емоцію зацікавленоcті (Izard, 1991). Позитивні емоції не тільки зумовлюють підйом активності організму, але й змістовно сприяють злагодженості й конструктивності реалізації когнітивних процесів і дій. Всупереч цьому емоція гніву, 
rower with this result. Besides, basal emotions are not only the expresser of needs or the basis of the structure of motivation of the subject, but they also determine the patterns of activation or deactivation. Such patterns are saturated with emotional experience and can be consciously used by the rowers in the processes of self-regulation for the achievement of the necessary level of motivation and the "entering" a zone of the optimal functioning (Gould et al., 2017).

In competitive practice, the motivational component of the relevant mobilization attitude of athletes is formed under the influence of emotional stimuli of the environment and, especially, relatives (see table 2). The actualization of emotional features of the personality traits also has a different contribution to competitive motivation: emotional stability is positive; anxiety (concern) is negative. These components of the emotional factor, as well as competitive stressors, in their initiation are beyond the control of athlete's consciousness, but they can directly affect both the effectiveness of rowing and the actualization of mental resources of self-mobilization (see table 3 ). The latter relates to the use of verbal formulas of self-suggestion (self-order, self-persuasion, self-encouragement, selflessness).

Conscious regulation of the emotions and motivation for success in the process of competitive self-mobilization is the most effective under the conditions of the use of the formula of self-encouragement and image self-identification with "a powerful mechanism" or "ferocious beast" by the participants. In general, the participants typically use the verbal formulas for self-mobilization (see fig.1). And it makes sense during the preparation for competitions and at the start, but in the context of strong-minded control of the expedient implementation of accumulated boost for actions and without violating the regime of athlete's activities (Agisheva et al., 1982). However, when passing a distance, the actualization of image construct like "a powerful mechanism" is more relevant, and the verbal self-suggestion ("I am enduring. I am strong. I can do it") influences more negatively.

In the complex structure of the subject's self-regulation, semantic redefinition of cognitive component contributes to the changes in the emotional response, facilitates the rebuilding of the whole structure of the activity system хоча й сприяє суттєвій активізації організму, але виявляється деструктивною. Такий результат повністю відповідає тим твердженням теорії диференційних емоцій, що генетично пов'язують гнів з імпульсивністю та порушенням злагодженості дій людини (Ekman, 2004; Izard, 1991). Разом із цим примітним $є$ й отриманий зв'язок емоцій радості та задоволення 3 мотивацією успіху. Цим результатом стверджується насамперед мотиваційна, а не компенсаторна функція емоцій в структурі діяльності спортсменів-веслувальників. До того ж, базальні емоції $\epsilon$ не тільки виразником потреб або основою структури мотивації суб'єкта, але вони визначають й патерни активації чи дезактивації. Такі насичені переживаннями патерни й можуть свідомо використовуватися веслувальниками в процесах саморегуляції для досягнення необхідного рівня мотивування та активності й для «потрапляння» в зону оптимального функціонування (Gould et al., 2017).

У змагальній практиці мотиваційний компонент актуальної мобілізаційної установки спортсменів формується під впливом емоціогенних стимулів середовища й, особливо, родичів (див. табл. 2). Різний внесок до змагальної мотивації має й актуалізація емоційних особливостей особистості: емоційна стійкість - позитивний; стурбованість (тривожність) - негативний. Ці складові емоційного фактору, як і змагальні стресори, у своїй ініціації непідконтрольні свідомості спортсмена, але вони можуть безпосередньо впливати як на ефективність веслування, так і на актуалізацію ментальних ресурсів самомобілізації (див. табл. 3). Останнє саме й відноситься до застосування словесних формул самоналаштування (самонаказ, самопереконання, самопідбадьорення, самовідданість).

Свідома регуляція емоцій та мотивації успіху у процесі змагальної самомобілізації найбільш ефективна за умови застосування досліджуваними формули самоподбадьорення та образної самоідентифікації з "могутнім механізмом" або з "лютим звіром". Загалом досліджувані набагато частіше для самомобілізації застосовують словесні формули (див. рис. 1). I це цілком виправдовує себе в підготовці до змагань і на старті, але за умови вольового контролю доцільної реалізації накопи- 
(Prokhorov, 2017). Image self-identification of a rower with a "powerful mechanism" changes the conceptual attitude of his actions and results in his acquisition, through associative chains, of such important properties of the functioning of the "mechanism" as coherence, stability, indefatigability, energy, integrity, expediency. At the same time, it is very common when a participant untimely identifies himself with the Winner due to the support of a coach and friends, but it also can be a motivator for competition or raises additional difficulties in the process of the competition. As it is marked in literature, for example, by D. Gould and his colleagues, an athlete has to focus on the very process during the competition but not to provoke dissociation effects in time and content (Gould et al., 2017).

The need not for a non-compensatory emotional reaction but coordinated motivated self-mobilization arises when an athlete experiences the emotions of anger. However, under such circumstances, measures which are aimed exclusively at reducing activity may inadmissibly degrade the level of energy of an athlete's efforts. In the very process of self-regulation, the potential to control both anger and any emotion is opened due to the balanced expedient use of the selected emotional and cognitive structures acting as mental resources (Izard, 1991).

When the subject uses image constructs and verbal formulas for the self-mobilization, he changes the self-control over actions performance along with the change of sense of attitude to the reality. Thus, the specified self-control provides the involvement of volitional powers in the actual competitive attitude of the athlete. The volitional component in combination with the components of the emotional factor acts in the complex of emotional and volitional potential as the most important determinant of the self-mobilization of professional rowers (Cheban, 2018). Consequently, the athlete treats the image of a "ferocious beast" not only a symbol of unconscious "explosion" of mental energy but also a symbol of the intense level of energy, self-confidence, resoluteness, and self-actualization. For this very reason, it should be reckoned the participants correlate the image of a "ferocious beast" with the "powerful mechanism" ( $R s=$ $.630 ; \mathrm{p}<.001$ ) which, in turn, is positively associated with pleasure $(R s=.331 ; \mathrm{p}=.035)$ and nega- ченого заряду енергії дій і без порушення режиму життєдіяльності спортсмена (Agisheva et al., 1982). Однак під час проходження змагальної дистанції для самомобілізації найбільш прийнятною виявляється актуалізація образного конструкту на кшталт "могутнього механізму", а пряме словесне самонавіювання (“Я витривалий. Я сильний. Я зможу") впливає вже більше негативно.

В складній структурі саморегуляції суб'єкта смислове перевизначення когнітивного компоненту сприяє змінам в емоційному реагуванні. Воно веде до перебудови всієї структури системи діяльності (Prokhorov, 2017). Образна самоідентифікація веслувальника 3 "могутнім механізмом" змінює смислову установку його дій. Вона $є$ наслідком присвоєння ним через асоціативні ланцюги таких важливих властивостей функціонування "механізму", як: злагодженість, стійкість, невтомність, енергійність, цілісність, доцільність. Поряд із цим досить часте і таке, що має підтримку тренера та друзів, завчасне уявлення досліджуваними себе як Переможця (див. рис. 1), хоча й може бути мотиватором до змагань, в процесі самого змагання швидше створює додаткові труднощі, аніж допомагає. Як зазначено в літературі, зокрема Д. Гулдом зі співавторами, спортсмен під час змагання повинен зосереджуватися на самому процесі дій, а не на бажаному результаті, й не провокувати ефектів дисоціації за часом та змістом (Gould et al., 2017).

Необхідність не компенсаторної емоційної реакції, а скоординованої вмотивованої самомобілізації, вочевидь постає при переживанні спортсменом емоції гніву. Висока імпульсивність рухів разом з підвищеної активністю у стані гніву сприяє руйнуванню складно скоординованих дій веслувальника. Однаку таких обставинах заходи, які спрямовані тільки на зниження активності, можуть й неприпустимо зменшувати енергійність зусиль спортсмена. Саме у процесі саморегуляції й відкриваються можливості керування як гнівом, так і будьякою емоцією, через виважене доцільне застосування в якості ментальних ресурсів спеціально відібраних афективно-когнітивних структур (Izard, 1991).

Коли для самомобілізації суб'єкт використовує образні конструкти і словесні формули, 


\section{Emotional factor of competitive self-mobilization of professional rowers}

tively - with anger (Rs=-.447; $\mathrm{p}=.003)$ and sadness (Rs=-.368; $\mathrm{p}=.018)$.

\section{Conclusions}

1. Positive emotions of joy and pleasure, which are defined as basal in differential emotions theory, are predominant components of the emotional state of life activities of the professional rowers. These emotions strengthen the motivation for success and the focus on competitive self-mobilization to overcome the influence of stressors of the competitive situation.The activating emotion of anger contributes to the violation of difficulty coordinating rowing techniques and reduces the effectiveness of self-mobilization of athletes due to the characteristic increase in the impulsiveness of the reaction.

2. Emotional reactions of professional rowers involuntarily emerge under the influence of some external and internal stimuli of the competitive situation, which also include stressors of fatigue and anxiety about the performance results. Such emotional stimuli of external conditions as friends, fans, natural conditions, and, above all, relatives, inspire athletes to use mental resources in the form of verbal formulas for competitive self-mobilization. The participants associate a coach and friends with an untimely self-identification with the "Winner" of the competition. Emotional personality traits accordingly affect (emotional stability - positively; anxiety - negatively) the overall effectiveness and key components of the process of self-mobilization: motivation for success, the use of mental resources.

3. Professional rowers associate the promotion of the motivation for success and overall effectiveness of competitive self-mobilization with the conscious actualization of affective and cognitive structures represented by image constructs of "powerful mechanism" and "ferocious beast" and verbal forms of indirect self-suggestion (self-encouragement, selflessness).

4. Professional rowers direct the competitive self-mobilization at the achievement of the optimum of motivation and fine coordination of dynamic movements. For self-mobilization, the athlete activates the emotional and volitional potential if required, which is an appropriate combination of volitional qualities with an emotional factor that includes

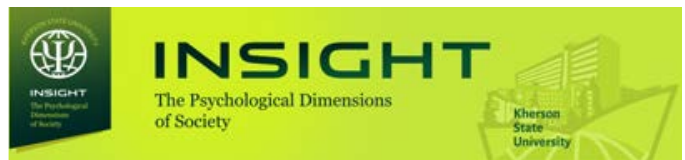

разом із зміною смислу відношень дійсності він змінює й самоконтроль виконання дій. При цьому вказаний самоконтроль передбачає долучення до актуальної змагальної установки спортсмена вольових якостей. Вольовий компонент в поєднанні зі складовими емоційного фактору виступає в комплексі емоційно-вольового потенціалу як найважливіша детермінанта самомобілізації спортсменів-веслувальників (Cheban et al., 2020). I тоді для спортсмена образ “лютого звіра" постає вже не як символ неусвідомлюваного “вибуху" психічної енергії, а як символ яскравої енергійності, впевненості у собі, рішучості, самоствердження. Саме тому, як слід вважати, образ “лютого звіра” у досліджуваних стійко пов'язується з “могутнім механізмом” (Rs=.630; $\mathrm{p}<.001)$, який, у свою чергу, позитивно асоціюється з задоволенням (Rs=.331; $\mathrm{p}=.035)$ і негативно - 3 гнівом (Rs=-.447; $\mathrm{p}=.003)$ та сумом (Rs=-.368; $\mathrm{p}=.018)$.

\section{Висновки}

1. У спортсменів-веслувальників провідними складовими емоційного фону життєдіяльності $\epsilon$ позитивні емоції радості та задоволення, визначені як базальні в теорії диференційних емоцій. Ці емоції підсилюють мотивацію успіху й установку на змагальну самомобілізацію для подолання впливу стресорів змагальної ситуації. Активуюча емоція гніву через характерне підвищення імпульсивності реагування сприяє порушенню складно координованої техніки веслування і знижує ефективність самомобілізації спортсменів.

2. Емоційні реакції спортсменів-веслувальників мимоволі виникають під впливом низки зовнішніх на внутрішніх стимулів змагальної ситуації, до яких відносяться й стресори втоми та тривоги за результати виступу. Такі емоціогенні стимули зовнішніх умов, як друзі, вболівальники, природні умови, i, насамперед, родичі, надихають спортсменів на застосування для змагальної самомобілізації ментальних ресурсів у вигляді словесних формул. Тренер та друзі пов'язуються досліджуваними 3 дочасним уявленням себе як "Переможця" змагань. Емоційні особистісні особливості відповідно впливають (емоційна стійкість - позитивно; стурбованість - негативно) на загальну ефективність та ключові 
emotional stimuli of the competitive situation and affective and cognitive structures of experience (mental resources).

It is expedient to conduct further research for identifying the functional relations of emotional and volitional components of the competitive self-mobilization of professional rowers.

\section{References}

Agisheva, N. K., Alekseev, A. V., Vish, I. M. \& Filatov, A.T. (1982). Emotional-volitional training of athletes. Kiyv: Zdorovia.

Alekrinskis, A., Bulotienè, D. \& Dagytè, R. (2019). Peculiarities of pre-competition emotional state of the Lithuanian national kayak and canoe rowing team members and junior kayakers and canoeists. Sporto mokslas / Sport Science, 95(1), 12-17. DOI: 10.15823/sm.2019.95.2

Cheban, Yu. V. (2018). The level of development of the basic volitional qualities of highly qualified rowing athletes. Science and education, 9-10, 72-77.

Chebykin, O., Kosianova, O. (2017). Deceitfulness according to the indicators of emotional maturity methodology and polygraph examination. Science and Education, 7, 21-31 DOI: 10.24195/24144665-2017-7-4

Ekman, P. (2004). Emotions Revealed: Recognizing Faces and Feelings to Improve Communication and Emotional Life. New York: Henry Holt and Company.

Fress, P. (1975). Emotions. Experimental psychology. Vol.5 / Edited by P. Fress, G. Piage. Moscow: Progress, 111-195.

Gould, D., Flett, M. R. \& Bean, E. (2009). Mental preparation for training and competition. Chapter 6 of the book "Sports Psychology"/ Edited by B.V. Brewer. Wiley-Blackwell. 53-63.

Izard, C. E. (1991). The Psychology of Emotions. New York: Plenum.

Kolumbet, A. N. (2017). Dynamic of kayak rowing technique in the process of competition activity. Pedagogics, psychology, medical-biological problems of physical training and sports, 21(4), 175-179. DOI: 10.15561/18189172.2017.0405

McCormick, A., Meijen, C. \& Marcora, S. (2018). Effects of a Motivational Self-Talk Intervention for Endurance Athletes Completing an Ultramarathon. Sport psychologist,32(1), Special Issue: SI, 42-50.

Miarka, B., Bello, F. D., Brito, C. J., Vaz, M. \& Vecchio, F. B. (2018). Biomechanics of rowing: kinematic, kinetic and electromyographic aspects. Journal of Physical Education and Sport,18(1), 193-202. DOI: 10.7752/jpes.2018.01025

Popovych, I. S., Blynova, O. Ye., Bokshan, H. I., Nosov, P. S., Kovalchuk, Z. Ya., Piletska, L. S. \& Ber- складові процесу самомобілізації: мотивацію успіху, застосування ментальних ресурсів.

3. Підвищення мотивації успіху й загальної ефективності змагальної самомобілізації у спортсменів-веслувальників пов'язане зі свідомою актуалізацією афективно-когнітивних структур, представлених образними конструктами "могутнього механізму" та "лютого звіра", й словесними формами непрямого самонавіювання (самопідбадьорення, самовідданість).

4. Змагальну самомобілізацію у спортсменів-веслувальників спрямовано на досягнення оптимальної мотивації та на витончену координацію енергійних рухів. Задля самомобілізації, спортсмен за необхідністю активує емоційно-вольовий потенціал, який є доцільним поєднанням вольових якостей з емоційним фактором, що охоплює емоціогенні стимули змагальної ситуації й афективно-когнітивні структури досвіду (ментальні ресурси).

Подальше дослідження доцільно спрямувати на визначення функціональних зв'язків емоційних та вольових складових змагальної самомобілізації спортсменіввеслувальників.

\section{Список використаних джерел}

Агішева Н. К., Алексєєв А. В., Виш, І. М., Філатов А. Т. Емоційно-вольова підготівка спортсменів. Київ: Здоров'я, 1982, 296 с.

Alekrinskis A., Bulotienè D., Dagytè, R. Pecu- liarities of pre-competition emotionalstate of the Lithuanian national kayak and canoe rowing team members and junior kayakers and canoeists. Sporto mokslas / Sport Science, 95(1), 2019. C. 12-17. DOI: $10.15823 / \mathrm{sm} .2019 .95 .2$

Cheban, Yu., Chebykin, O., Plokhikh, V. \& Massanov, A. Mental resources for the self-mobilization of rowing athletes. Journal of Physical Education and Sport, Vol.20 (3), 2020, pp. 1580-1589. DOI:10.7752/ jpes.2020.03216

Chebykin, O., Kosianova, O. Deceitfulness according to the indicators of emotional maturity methodology and polygraph examination. Science and Education, 7, 2017, pp. 21-31. DOI: 10.24195/2414- 46652017-7-4

Ekman P. Emotions Revealed: Recognizing Faces and Feelings to Improve Communication and Emotional Life (274 p.). New York: Henry Holt and Company. 2004.

Фресс П. Эмоции. Экспериментальна психология. Т. 5 / Под ред. П. Фресс и Ж. Пиаже. Москва: Прогресс, 1975. С. 111-195. 
bentsev, V. I. (2019). The Research of the Mental States of Expecting a Victory in Men Mini-football Teams. Journal of Physical Education and Sport, 19(4), 2343-2351. DOI:10.7752/jpes.2019.04355

Prokhorov, A. O. (2017). Technologies of mental self-regulation. Kharkov: Gumanitarnyj centr.

Strykalenko, Y., Shalar, O., Huzar, V., Andrieieva, R., Zhosan, I. \& Bazylyev, S. (2019). Influence of the maximum force indicators on the efficiency of passing the distance in academic rowing. Journal of Physical Education and Sport, 19(3), 1507-1512. DOI:10.7752/jpes.2019.03218

Wallace, P. J., McKinlay, B. J., Coletta, N. A., Vlaar, J. I., Taber, M. J., Wilson, P. M. \& Cheung, S. S. (2017). Effects of Motivational Self-Talk on Endurance and Cognitive Performance in the Heat. Medicine \& Science in Sports \& Exercise, 49(1), 191-199.
Gould D., Flett M. R., Bean E. Mental preparation for training and competition. Chapter 6 of the book "Sports Psychology" / Edited by B.V. Brewer. Wiley-Blackwell, 2009, pp. 53-63.

Izard C. E. The Psychology of Emotions. (p. 452.). New York: Plenum. 1991.

Kolumbet, A. N. Dynamic of kayak rowing tech- nique in the process of competition activity. Pedagogics, psychology, medical-biological problems of physical training and sports, 21(4), 2017, pp. 175-179. doi :10.15561/18189172.2017.0405

McCormick, A., Meijen C., Marcora S. Effects of a Motivational Self-Talk Intervention for Endurance Athletes Completing an Ultramarathon. Sport psychologist, 32(1), Special Issue: SI, 2018, pp. 42-50.

Miarka B., Bello F. D., Brito C. J., Vaz M., Vecchio F. B. Biomechanics of rowing: kinematic, kinetic and electromyographic aspects. Journal of Physical Education and Sport, 18(1), 2018, pp. 193-202. DOI:10.7752/jpes.2018.01025

Popovych I. S., Blynova O. Ye., Bokshan H. I., Nosov P. S., Kovalchuk Z. Ya., Piletska L. S. Berbentsev V. I. The Research of the Mental States of Expecting a Victory in Men Mini-football Teams. Journal of Physical Education and Sport, 19(4), 2019, pp. 23432351. DOI: $10.7752 /$ jpes.2019.04355

Прохоров А. О. Технологии психической саморегуляции. Харьков: Гуманитарный центр, 2017, 360 c.

Strykalenko Y., Shalar O., Huzar, V., Andrieieva, R., Zhosan, I. \& Bazylyev, S. Influence of the maximum force indicators on the efficiency of passing the distance in academic rowing. Journal of Physical Education and Sport, 19 (3), 2019, pp. 15071512. DOI: $10.7752 /$ jpes.2019.03218

Wallace P. J., McKinlay B. J., Coletta N. A., Vlaar J. I., Taber M. J., Wilson P. M., Cheung S. S. Effects of Motivational Self-Talk on Endurance and Cognitive Performance in the Heat. Medicine \& Science in Sports \& Exercise, 49(1), 2017, pp. 191-199. 